\title{
CORRELATION OF MIC WITH DISC SENSITIVITY TEST OF AMPICILLIN, AMOXYCILLINE AND TETRACYCLINE
}

\section{*A.K.M Shamsul Haque ${ }^{1},{ }^{* *}$ M.A. Samad Talukder ${ }^{2}{ }^{*}$ Md. Rafiquzzaman ${ }^{3}$, * Sakina Sultana ${ }^{4}$. Pijus Saha ${ }^{5}$ and ** A. Hakim Chakladar 6 \\ Summary}

The aim of the study was to find the correlation of minimum inhibitory concentration (MIC) with disc sensitivity test of ampicillin, amoxycillin and tetracycline near the end of shelf life. The methods used were tube dilution and disc diffusion test. Each antibiotic tested was from ten different pharmaceutical companies. All the antibiotics were purchased near the end of shelf life. There is an approximately linear relation between $\log _{2}$ MIC and the diameter of zone of inhibition for standard antibiotics and sample antibiotics of some pharmaceutical companies. Other sample antibiotics failed to show correlation. Therefore it may be concluded that some antibiotics become substandared at the end of shelf life. Doctors and patients should be aware of this problem.

\section{Introduction}

Antibiotics are the substances produced by microorganisms, that can inhibit the growth of other organisms or even destroy them when; used clinically ${ }^{1}$. Antibiotics are very essential drugs for the treatment of many infections ${ }^{2}$. If they are of low biopotency, they may develop drug resistance against the microorganism. Acquired antibiotic resistance may develop in becteria by coming in contact with the antibiotics of low biopotency ${ }^{3}$. 'Shelf life' of an antibiotic is the total time extending from the period of production to the period of consumption by the patient ${ }^{4}$. Activity of antibiotics may be over during shelf life and at the same time their biopotency may be decreased. Thus antibiotics may become substandard. People may be victimized and lose their hard earned money if they buy such substandard antibioitics. Organisms may develop drug resistance and their disease may become complicated. It is a mater of regret that most of the people in our country do not check the expiry date, even sometime they do not know about the expiry date of a drug. It is also not possible for them to check the quality of the antibiotics. In this situation the prime responsibility of examining the quality of drugs mainly goes to the drug administration and the government's drug testing authorities. The aim of the study was to find correlation of minimum inhibitory concentration (MIC) with disc sensitivity test of ampicillin, amoxycillin and tetracycline near the end of shelf life to predict about the biopotency of the studied antibiotics.

1. A.K.M. Shamsul Haque B. Pharm (Hons), M. Pharm (Thesis student)

2. Prof. Muhammad Abdus Samad Talukder MBBS, Ph. D. M. Sc,Dip Bact. DTM\&H

3. Dr. Mohammad Rafiquzzaman M. Sc. Ph. D

4. Mrs. Sakina Sultana M. Pharm, M.S

5. Pijus Saha M. Pharm

6. Dr. A. Hakim Chakladar MBBS, PGT in Bact. (Finland)

-1. Dept. of Pharmacy, Jahangirnagar University. Savar. Dhaka-1342.

$*$ 2. Gonoshasthaya Vaccine Research and Diagnostic Laboratory, Savar, Dhaka-1350. 


\section{Materials and Methods}

Three antibioitic sampls ampicilline, amoxycllline and tetracycline were purchased near the end of shelf life from medicine shops of Dhaka, Savar and Brahmanbaria. Each antibiotic was of ten different pharmaceutical companies. The control organisms Escherichia. colf (ATCC 25922) and Staphylococcus aureus (ATCC 25923) were obtained from ICDDR, B. Other isloates were from patients. Standard antibiotics were of $\mathrm{BDH}$ and those were collected from Gonoshasthya Pharmaceuticals. Fresh home made discs of three antibiotics were prepared and Mueller-Hinton agar media was used in this study. MIC were tested by doubling dilútion for ampicillin $64-2 \mathrm{mcg} / \mathrm{ml}$, amoxycillin $32-1 \mathrm{mcg} / \mathrm{ml}$ and tetracycline $32-$ $1 \mathrm{mcg} / \mathrm{ml}$. Discs were prepared with ampicillin $10 \mathrm{mcg} /$ disc, amoxycillin $10 \mathrm{mcg} / \mathrm{disc}$ and tetracycline $30 \mathrm{mcg} /$ disc.

Methods used were tube dilution ${ }^{5}$ for MIC and disc diffusion ${ }^{6}$ for zone of inhibition or sensitivity test in Mueller-Hinton agar media.

\section{Results}

Coorelation btween $\log _{2}$ MIC and size of zone of inhibition was obtained for three standard antibiotics viz. ampicillin, amoxycillin and tetracycline against two control organisms. The results are presented in the Table I. The graphical representation of correlation for standard antiblotics are also shown in the Fig-1. This figure indicates that with the increase of MIC for any standard antibiotic against different control organisms the zone of inhibition or disc diameter is decreased or with the decrease of MIC the zone of inhibition is increased within the claimed range $1-5 \log _{2} \mathrm{MIC}$. For standard antibiotics such phenomena is expected i.e. $\log _{2}$ MIC will be inversely proportional to the disc diameter.

Out of total 30 experimental different sample antibiotics (Ampicillin-10. Amoxycillin10 and Tetracycline-10) four ampicillin, five amoxycillin and two tetracycline did not show correlation but rest of the sample antibioitics showed correlation. Six representative data of those sample antibiotics are given in Table II to show correlation between MIC and zone size. It is evident from the Table II that some representative sample antibiotics (Med794, GR1095m Am 1094) fail to correlate between $\log _{2}$. MIC and zone diameter because either the concentration of MIC cross the experimental limit or size of zone of inhibition is below the range of drug resistance. It is also clear from the Table II that other representative sample antibiotics (F395. G1095, IS1 193) correlate between $\log _{2}$ MIC and zone diameter. There is a good correlation between $\log _{2}$ MIC and diameter of inhibition for standard antibilotics (Table I) as well as some sample antibiotics (Table II). But some other sample antibiotics failed to show correlation (Table II) near end of shell life.

\section{Discussion}

An antibiotic shall remain satisfactory when it is stored under expected or desired storage conditions during it's shelf life period. Satisfactory antibiotic means antibiotic must be therapeutically, chemically and environmentally stable. People of our country are poor. For buying antibiotics they have to pay a lion share of their income. So, antibiotics which they buy must have the desired efficacy to serve the purpose. From this study it is found that some sample antibiotics failed to correlate between $\log _{2} \mathrm{MIC}$ and zone diameter (Table II). So, it can be said that those sample 
antibiotics were spurious and substandard. This finding in turn suggest that some unreliable companies manufacture and supply spurious and substandard life saving antibiotics to the market. This statement is supported by the previous report ${ }^{7}$ about the supply of spurious and substandard over the counter drugs such as paracetamol. Low biopotency found in the sample antibiotics in this study might be also due to lack of proper storage conditions of the antibiotics during their shelf life period. Under improper stroage conditions antibiiotics may degrade and lose biopotency by hydrolysis, Oxidation, autoxidation, isomerization, polymerization, decarboxylation with the influence of temperature, moisture, light and radiation 8 .

All the antibitiotic (s) manufacturing pharmaceutical companies should be honest, sincere and bear the responsibilities of quality antibiotics production. Doctors should be cautious and try to avoid prescribing substandard antibilotics of unreliable companies. At the same time users should purchase freshly manufactured antibiotics by checking manufacturing and expiry date of the desired antibiotics.

\section{Acknowledgments}

We are grateful to the microbiology department of the ICDDR,B for supplying us American Type Culture Collection control organisms and also grateful to the Gonoshasthaya Pharmaceuticals for supplying standard antibiotlcs. Authors are indebted to Gonoshasthaya Vaccine Research and Diagnostic Laboratory authority and staff for providing laboratory facilities to perform this study smoothly.

Table I : Minimum Inhibitory Concentration (MIC) log2 MIC and Zone Size of Three Standard Antiblotics Against Two Control Organisms.

\begin{tabular}{|c|c|c|c|c|c|c|}
\hline \multirow[t]{2}{*}{$\begin{array}{c}\text { Standard } \\
\text { Antibiotics } \\
\end{array}$} & \multicolumn{3}{|c|}{$\begin{array}{l}\text { Staphylococcus aureus } \\
\text { (1) ATCC } 25923\end{array}$} & \multicolumn{3}{|c|}{$\begin{array}{l}\text { Eschertichia coli } \\
\text { (2) ATCC } 25922\end{array}$} \\
\hline & $\begin{array}{c}\mathrm{MIC} \\
(\mathrm{mcg} / \mathrm{ml})\end{array}$ & $\begin{array}{l}\log 2 \\
\text { MIC } \\
\text { (m.m) }\end{array}$ & $\begin{array}{l}\text { zone } \\
\text { Dia }\end{array}$ & $\begin{array}{c}\text { MIC } \\
(\mathrm{mcg} / \mathrm{ml})\end{array}$ & $\begin{array}{c}\log 2 \\
\text { MIC } \\
(\mathrm{m} \cdot \mathrm{m})\end{array}$ & $\begin{array}{c}\text { Zone } \\
\text { Dia }\end{array}$ \\
\hline Ampicillin & 4 & 2 & 29 & 16 & 4 & 22 \\
\hline Amoxycillin & 16 & 4 & 30 & 32 & 5 & 16 \\
\hline Tetracycline & 16 & 4 & 28 & 2 & 1 & 31 \\
\hline
\end{tabular}




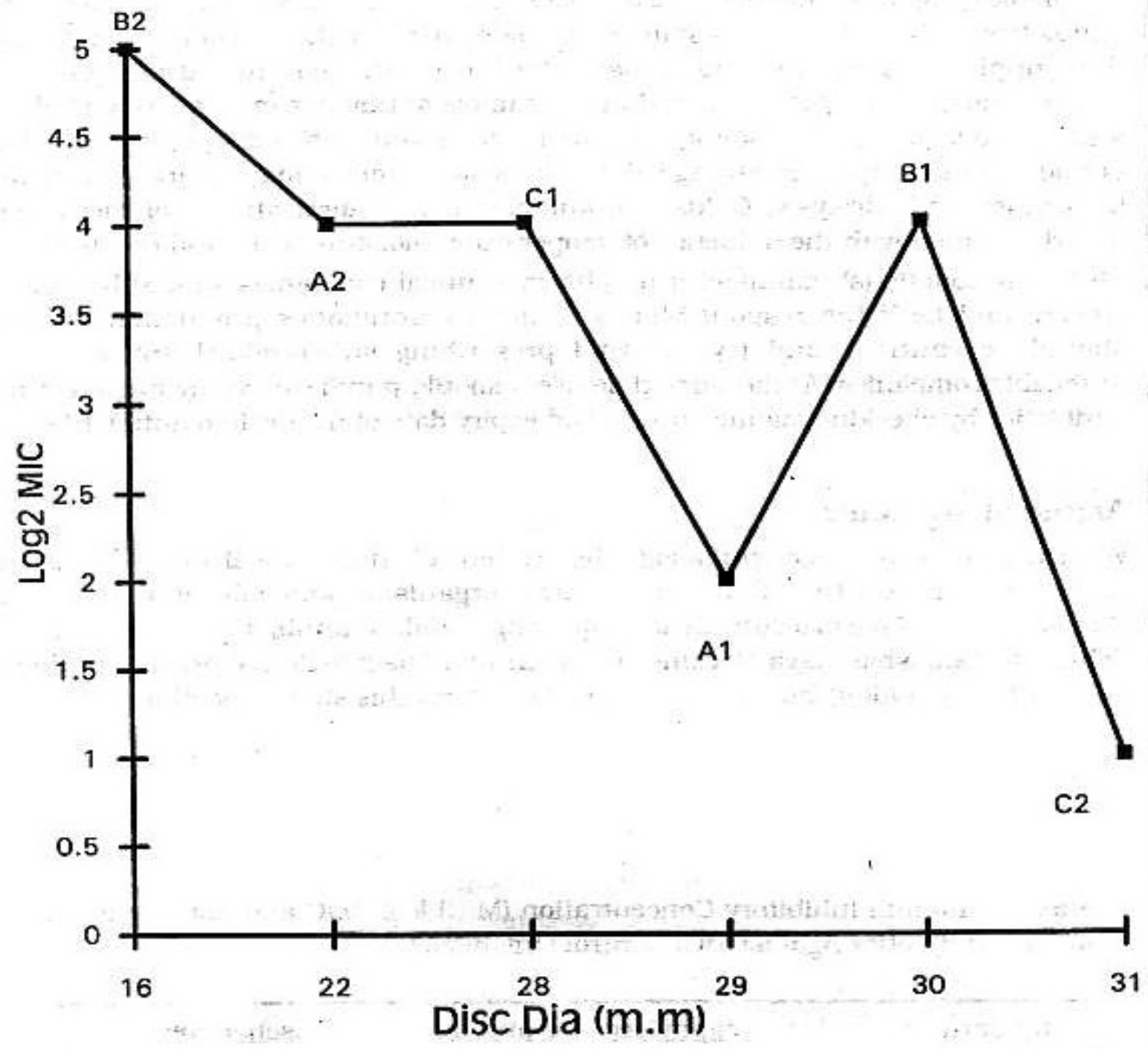

A1 = Ampicillin against Staphylococcus aureus.

B1 $=$ Amoxycillin against Staphylococcus aureus.

C1 = Tetracycline against Staphylococcus aureus.

A2 = Ampicillin against Escherichia coli.

B2 = Amoxycillin against Escherichia coli

C2 = Tetracycline against Escherichia coli.

Fig 1: Graphic view showing correlation between disc sensitivsity test with $\log 2$ MIC of three standard antibioties against two control organisms. 
Table II : Representative Data of Some Sample Antibiotics to Show Correlation Between MIC and Zone Size.

\begin{tabular}{|c|c|c|c|c|c|c|}
\hline \multirow[t]{2}{*}{$\begin{array}{l}\text { Sample } \\
\text { Antibiotics } \\
\text { /code }\end{array}$} & \multicolumn{3}{|c|}{$\frac{\text { Escherichia coli }}{\text { ATCC } 25922}$} & \multicolumn{3}{|c|}{$\frac{\text { Staphylococcus aureus }}{\text { ATCC } 25923}$} \\
\hline & $\begin{array}{c}\text { MIC } \\
(\mathrm{mcg} / \mathrm{ml})\end{array}$ & $\begin{array}{l}\log _{2} \\
\mathrm{MIC} \\
(\mathrm{m} . \mathrm{m}) \\
\end{array}$ & $\begin{array}{c}\text { zone } \\
\text { Dia }\end{array}$ & $\begin{array}{c}\text { MIC } \\
(\mathrm{mcg} / \mathrm{ml})\end{array}$ & $\begin{array}{l}\log 2 \\
\text { MIC } \\
(\mathrm{m} . \mathrm{m})\end{array}$ & $\begin{array}{l}\text { Zone } \\
\text { Dia }\end{array}$ \\
\hline $\begin{array}{l}\text { Ampicillin } \\
\text { (Med794) }\end{array}$ & $>64$ & $>6$ & 0 & $>64$ & $>6$ & 0 \\
\hline $\begin{array}{l}\text { Ampicillin } \\
\text { (F395) }\end{array}$ & 16 & 4 & 23 & 16 & 4 & 29 \\
\hline $\begin{array}{l}\text { Amoxycillin } \\
\text { (GR1095) }\end{array}$ & $>32$ & $>5$ & 16 & $>32$ & $>5$ & 15 \\
\hline $\begin{array}{l}\text { Amoxycillin } \\
\text { (G1095) }\end{array}$ & 32 & 5 & 19 & 8 & 3 & 30 \\
\hline $\begin{array}{l}\text { Tetracycline } \\
\text { (AM1094) }\end{array}$ & $>32$ & $>5$ & 25 & $>32$ & 5 & 23 \\
\hline $\begin{array}{l}\text { Tetracycline } \\
\text { (IS1193) }\end{array}$ & 8 & 3 & 27 & 32 & 5 & 28 \\
\hline
\end{tabular}

\section{References :}

1. Garrod, L.P., Lambert, H.P., O' Grady, F. The Evolution of Antt-Microbic Drugs, In : Antibiotic and Chemotherapy. 4th ed. Churchill Livingstone, Edingurgh, London and New York, 1973. P 1-11

2. Salam, M. A. Shigellosis : Chemotherapeutic Strategies. In : 4th Western Pacific Congress on Chemotherapy and Infectious Diseases, Manila, Philippines, Supplement to JAMA Southeast Asia. December, 1994; 10: P 50-54

3. Sleigh, J.D, Timbury, M.C. Antimicrobial therapy. In : Notes on Medical Bacteriology. 4th ed, Churchill Livingstone, Edinburgh London and Tokyo, 1994. P 367-388

4. Ferdous, A.J. Jalil, R. Dictionary of Pharmaceutical Technology. Dhaka ISBN 98N-300070-6, 1994. P 126

5. Garrod, L.P. Lambert, H.P.O' Grady, F. Waterworth, P.M. Laboratory Control. In : Antibiotic and Chemotherapy. 4th ed. Churchill Living stone. Edinburgh London and New York. 1973. P 490-531

6. Vandepitte, J. Engbaek, K. Plot, P. and Heuck, C.C. Antimicrobial susceptibility testing: In : Basic Laboratory Procedures in Clinical Bacteriology. World Health Organisation. Geneva. 1991. P 78-95

7. Saha, P. Gaulity of marketed Over The Counter (OTC) drugs in Bangladesh : paracetamol-A case study. M. pharm Thesis. Dept. of Pharmacy, Jahangirnagar University, Savar, Dhaka. September, 1992. P 50-52

8. Rawlines, E. A. Drug stability. In : Bentley's Text book of pharmaceutics. 8th ed. ELBS and Baulliere Tindall, London, 1982, p 140-149 